\title{
Expansion of renewable energy resources and energy- conscious behaviour at the University of Szeged
}

\author{
László Gyarmati \\ Management, University of Szeged, Study and Information Centre, Szeged 6722, Hungary
}

\begin{abstract}
At the University of Szeged, as the greenest University of Hungary, the sustainability project is built on two pillars. One of them is based on events and communication campaigns held regularly for the University citizens to prompt environmental-conscious behaviour, whereas the other is built on technological developments and on the extensive use of renewable energy resources. Thus the development of built environment and social responsibility both support the adequacy to sustainability requirements. The spreading of the effective solutions to making more and more buildings of the University energy efficient, numerous investments using renewable energy are also responsible for the decrease of the natural energy use of the institution contrary to the fact that the number of the buildings of the University of Szeged is continually increasing. It can be stated that the University of Szeged is committed to using renewable energy which is taken into consideration of each investment planning. The following examples confirm it: using geothermal cascade system for heating and cooling of five university bulidings, solar panels on 24 builidings and a unique technology of using the heat of wastewater to cool and heat one of the main bulidings of the university, namely the Study and Information Centre.
\end{abstract}

\section{Introduction}

The University of Szeged is one of the biggest universities in Hungary as it welcomes more than 6000 freshmen every September. The new students become members of an institution that regards the establishment of sense of vocation, the practical way of teaching and shaping of the students' approach as priority. The University is proud to have dozens of titles, some of which are in connection with conservation and sustainability.
Meeting the aims of the Third Mission of the Development Strategy of the University of Szeged, the Institution makes every effort each year to be more and more environmental conscious and 'green'[1].

Selective waste collection, use of solar energy, grey water and the heat of the waste are only some of those solutions owing to which our University was among the top 20 universities in the UI GreenMetric World University Ranking at 2014 [2] [Table 1.].

Table 1. Achievements of the University of Szeged in GreenMetric

\begin{tabular}{|c|c|c|c|c|}
\hline Year & $\begin{array}{l}\text { Place of the University of } \\
\text { Szeged/number of Universities } \\
\text { taking part in the ranking }\end{array}$ & $\begin{array}{l}\text { Proportion } \\
\text { Universities } \\
\text { behind the } \\
\text { Szeged }\end{array}$ & $\begin{array}{l}\text { of European } \\
\text { in the ranking } \\
\text { University of }\end{array}$ & $\begin{array}{l}\text { Difference in points between the } \\
\text { University in the first place and } \\
\text { the University of Szeged }\end{array}$ \\
\hline 2010 & $54 . / 95$ & & $44 \%$ & 2972 \\
\hline 2011 & $67 . / 178$ & & $70 \%$ & 2232 \\
\hline 2012 & $52 . / 215$ & & $82 \%$ & 1738 \\
\hline 2013 & $35 . / 301$ & & $88 \%$ & 1192 \\
\hline 2014 & $19 . / 360$ & & $92 \%$ & 885 \\
\hline 2015 & $29 . / 407$ & & $90 \%$ & 1038 \\
\hline 2016 & $107 . / 516$ & & $90 \%$ & 2751 \\
\hline 2017 & $88 . / 619$ & & $79 \%$ & 1179 \\
\hline
\end{tabular}

\section{On the way to sustainability}

At the beginnings, the green efforts of the University of Szeged got realized by individual initiatives and motivations. Seeing the success of these efforts, more and more university members and university units have joined these initiatives. It has all been started by the Management of the University of Szeged József Attila Study and Information Centre (henceforth SZTE TIK) (Fig. 1). Being the so called 'Heart of the University',

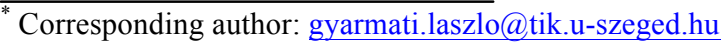


the Centre has been a combination of a Studying Area, a Teaching Area, a Service Area, a Conference Site and a Meeting Place for its daily 3000-3500 visitors for more than 13 years thus being the ideal place for showing examples of social responsibility to be followed. As a first step, the Management of SZTE TIK organized the "Earth Day" with tradition forming intention in 2008. Then in 2009, they won "The office taking the most steps towards being green" Award by following the guidelines of KÖVET Association for Sustainable Management. Seeing the success of this initiative, three other university units have joined the invitation the following year, The Rector's Office, The Student Service Office and the Dean's Office of the Faculty of Economics and Business Administration all of which were awarded with Creative Special Award.

Considering the visitors' needs, such developments had been carried out in the Centre, owing to which it was awarded the "Bicycle Friendly Workplace" title in 2010 and in 2011. Also in 2011, the Management of SZTE TIK launched the so called 'Green Commando' initiative which aimed at helping other university units become environment-friendly according to the guidelines of the 'green office' and by taking environment-friendly viewpoints into account. 2011 was again the year when the Green Commando initiative won the Public Award at the CSR Market event organized by KÖVET Association for Sustainable Management, which meant that a voluntary initiative of a university got national acknowledgement. Besides expanding the number of programmes which aimed at shaping the visitor's approach (e.g.: Earth Day, Earth Hour, Green Film Club, World Water Day, Fighting against Global Warming series of events, Furnace Tour, Charity events), technical developments and optimization processes to decrease the environmental impact of the Centre have also started. Furthermore, the regulation system of the first green Congress Centre of Hungary has also been established [3].

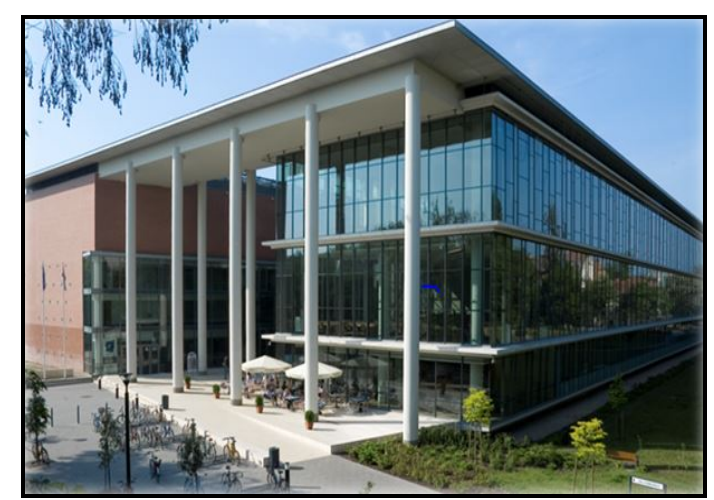

Fig. 1. Study and Information Centre - University of Szeged (SZTE TIK)

\subsection{Technical solutions}

Besides shaping the university members' and citizens' approach, the second pillar of the sustainability efforts of the University of Szeged is the continuous infrastructural development. The spreading of the effective solutions to making more and more university buildings energy efficient, (applying motion sensor switches and LED bulbs, optimizations of building management systems, shaping the environment-conscious behaviour of the employees, etc.), numerous investments using renewable energy are also responsible for the decrease of the natural energy use of the institution contrary to the fact that the number of the buildings of the University of Szeged is continually increasing (at present there are about 300 buildings of the University of Szeged scattered around in Szeged) [4]. It can be stated that the University of Szeged is committed to using renewable energy and it is taken into consideration at the beginning of each investment planning. The following examples confirm it: By using geothermal cascade system the heating and cooling of five university buildings are guaranteed [5]. Grey water system is applied at the central building of the University of Szeged owing to which rainwater has its secondary function. In the summer of 2015, the project of establishing the unique technology of using the heat of wastewater to cool and to heat the SZTE TIK was carried out (Fig. 3). With the help of this system, the heat energy gained from the wastewater having permanent temperature is used for heating and cooling of the building and it will be also possible to reduce the $\mathrm{CO}^{2}$ emission more than 300 tonnes [6].

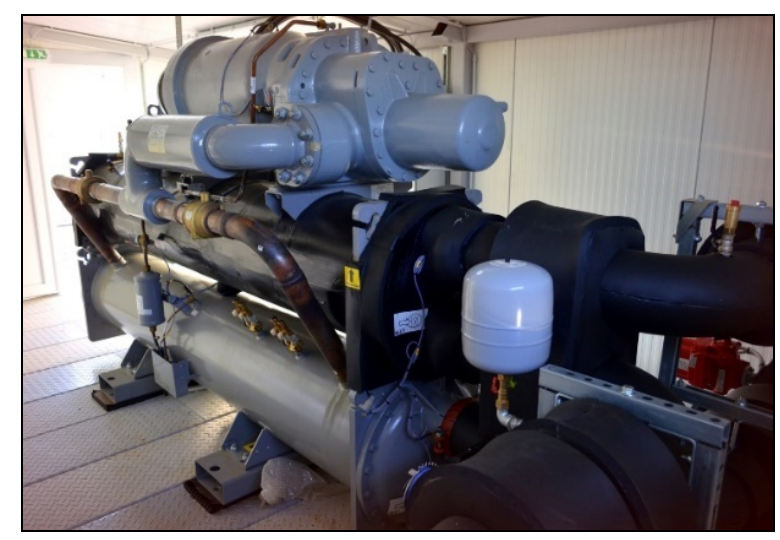

Fig. 3. Heat pump for usage of wastewater heat

\subsection{Widespread use of the solar panels}

In 2012, a new infrastructure development was launched owing to which solar panels were placed on top of some of the university buildings to produce energy with the help of solar energy. At that time 2754 pieces of solar panels were placed on top of 24 buildings of the University (Fig. 4). Besides the energy production of the solar panels, the emission of carbon dioxide also decreases as well as the proportion of sunlit surface, which results in energy consumption savings in the process of cooling, too. This way approximately 85700 Euros are saved each year. 


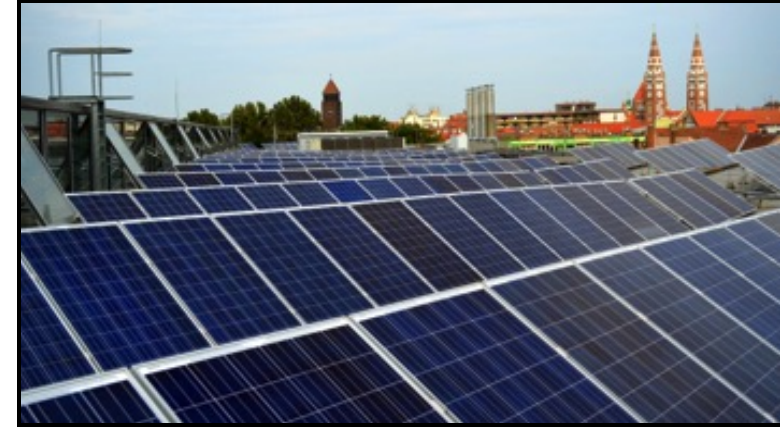

Fig. 4. Solar panels at the roof of SZTE TIK

The preparation of this project took long years as the first measures, calculations and site visits were carried out already in 2008. The reason for this was that the buildings of the University of Szeged can be found at every part of the city and because they were built in different times and styles so each of them had unique characteristics as for energetic aspect. The experts of the University examined more than 50 buildings from which the 24 most suitable for infrastructure development were chosen. At the process of choosing, one of the criteria was the appropriate building siting while the other was the 35-degree angular offset of the roof. In addition, the bearing capability of the roof had to be taken into consideration because of the weight of the solar panels and the extreme weather conditions.

Three years after this project was finished, the University successfully competed for a new project of establishing photovoltaic system. In this case again, The University of Szeged competed for an Environment and Energy Operative Programme to decrease its carbondioxide emission, and its energy costs as well as to harmonize the relation between people and environment.

With the help of this project 2040 pieces of solar panels have been placed on top of 18 buildings of the University that again results in saving 69841 Euros each year [7].

\subsection{Our companions, the university citizens.}

The popularity of the SZTE TIK ensures perfect opportunities for us to make the visitors get to know the green efforts of the University as well as it gives us the opportunity to get their feedback on it. Decreasing the environmental impact of the University depends just as much on the environment-conscious behaviour of the university students, citizens and event participants as on the commitment of the university employees.

Therefore, we use several communication channels to call the attention of our visitors to the environmental aspects in every spring and autumn semester. We plan a series of 'Get green during the registration with SZTE TIK' events for students registering for the following semester in order to draw their attention to the importance of environment-conscious behaviour (Fig. 5). We can reach more than 10.000 followers through the official Facebook site of the Centre. Furthermore, there are information panels placed all around the Centre to call the attention of its visitors to the conscious use of resources.

Besides raising the awareness of the visitors, it is also essential to inform the thousands of university professors, researchers and employees working in other fields, therefore a web-based internal social forum (so called coospace scene) was established in August 2014: Via coospace about 5.000 university citizens can get direct access to the information on the sustainable efforts of the university.

The Management of SZTE TIK has always considered it important to get direct feedback from the visitors on their expectations. According to the results of the visitors' satisfaction survey in 2012, the university citizens consider it extremely important that a state owned institution belonging to the Higher Education such as the SZTE TIK should be involved in social responsibility and should popularize the environmentconscious behaviour $(78 \%$ of the more than 1.000 respondents regarded this topic essential) [8].

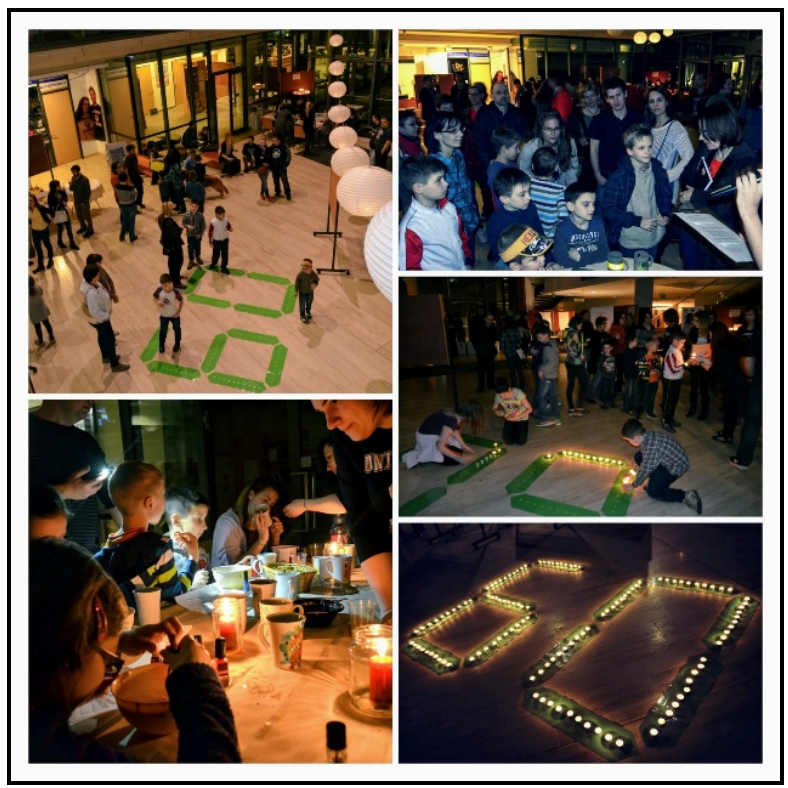

Fig. 5. Earth Hour event at the SZTE TIK (2015.)

\section{Summary}

The University of Szeged is committed to find and successfully compete for further projects which are to fund the use of renewable energy sources so that it can operate in more and more environment conscious and sustainable way. The University regards it important to find solutions to spreading the use of renewable energy in its buildings as well as to optimize its present technologies and improve their efficiency.

To keep the already achieved results, the University of Szeged has to take further steps in the following areas:

- defining the new short-term, mid-term and long-term strategies

- decreasing the greenhouse emission of the university within a set period of time 
- establishing a continuous feedback channel on the ecological footprint of each Faculty of the University of Szeged together with suggestions for further improvement

- implementing new investments by which further old institutions of the University of Szeged can get greener

- ensure that the goals set in the strategies are reached by continually monitoring and evaluating the figures and the results

- raising students' awareness of the importance of sustainability in workshops and community events

- establishing and monitoring an online forum for the teachers and students working and studying in the field of sustainability thus helping their co-operation

- co-operation with the representatives of civil services and local suppliers

\section{References}

1. University of Szeged Institution development plan, Available online at http://www.uszeged.hu/egyetemrol

141002/minosegfejlesztesi/szte-ift-2016-2020-

170124 , accessed on $27^{\text {th }}$, February 2018 (2016)

2. UI GreenMetric, 2010-2017. UI GreenMetric world university rankings. Available online at http://greenmetric.ui.ac.id/, accessed $27^{\text {th }}$, February 2018. (2010)
3. Green institution introduction, Available online at http://www.u-szeged.hu/tik/zoldintezmeny, accessed on $27^{\text {th }}$, February 2018 , (2018)

4. Press conference about GreenMetric results of University of Szeged 2013, Available online at http://www.u-

szeged.hu/sztehirek/hirarchivum/2013-

januar/magyarorszagon-szte, accessed on $27^{\text {th }}$, February 2018 (2013)

5. Press release about geothermal cascade system 2014, Available online at http://www.uszeged.hu/sztehirek/ sajtoarchivum-2014-1411058/sajtokozlemeny-ujszegedi, accessed on $27^{\text {th }}$, February 2018 (2014)

6. Project introduction homepage, Available online at http://www.u-szeged.hu/

fejlesztesiprojektek/projekt-bemutatasa/keop-20124-10-0-12-2013, accessed on $27^{\text {th }}$, February 2018 (2013)

7. Press conference about solar panel installations at the University of Szeged 2015, Available online at http://www.u-szeged.hu/sztehirek/2015-

augusztus/2040-napelem-18-egyetemi, accessed on $27^{\text {th }}$, February 2018 (2015)

8. SZTE TIK visitors' satisfaction survey - research report 2012. Available online at https://www.uszeged.hu/download.php? docID $=20692$, accessed on 27th, February 2012 (2012) 